\title{
PET/CT imaging in prostate cancer
}

\author{
Tara Barwick \\ From International Cancer Imaging Society Meeting and 15th Annual Teaching Course (ICIS 2015) \\ London, UK. 5-7 October 2015
}

Prostate cancer is the second most common male malignancy worldwide with a wide spectrum of biological behaviour ranging from fairly indolent disease to highly aggressive metastatic castrate resistant tumours. In the past decade there have been advances in therapies for treating advanced and recurrent prostate cancer and improved diagnostic/prognostic tools are required to refine the therapeutic approach at various stages in the management of prostate cancer patients.

For tumour staging/lesion localisation multiparametric prostate MRI is the modality of choice. Several PET tracers are proving more sensitive than conventional imaging techniques for early detection of lymph node and bone metastases. However a general limitation of PET is the spatial resolution which limits the reliability for detection of small lesions.

The use of F-18 fluoro-deoxyglucose (FDG) PET/CT in prostate cancer has been disappointing largely due to the fact that many prostate cancers have only low level glucose metabolism.

C-11/F-18 choline, markers of cell membrane metabolism, are now widely used in Europe and in certain UK centres particularly in the scenario of biochemical relapse and high risk staging with equivocal findings on conventional work-up [1-3]. However, in cases of biochemical relapse with low PSA rise and low PSA velocity, choline PET has low detection rates [4].

Prostate specific membrane antigen (PSMA), a cell surface membrane glycoprotein, is a promising target for the diagnosis and treatment of prostate cancer. Recently Ga-68 radiolabelled ligand targeted to PSMA has been introduced to a few European centres. Early data suggests this may be more sensitive than choline PET/CT in patients with biochemical failure and low PSA [5-7]. In addition it offers the opportunity for Lu-177 or Y-90 targeted radionuclide therapy.

\footnotetext{
Imperial College Healthcare NHS Trust and Imperial College, Division of
} Surgery and Cancer, UK

(C) 2015 Barwick This is an Open Access article distributed under the terms of the Creative Commons Attribution License (http:// creativecommons.org/licenses/by/4.0), which permits unrestricted use, distribution, and reproduction in any medium, provided the original work is properly cited. The Creative Commons Public Domain Dedication waiver (http://creativecommons.org/publicdomain/ zero/1.0/) applies to the data made available in this article, unless otherwise stated.

1. Contractor K, Challapalli A, Barwick T, Winkler M, Hellawell G, Hazell S, et al: Use of [11C]choline PET-CT as a noninvasive method for detecting pelvic lymph node status from prostate cancer and relationship with choline kinase expression. Clin Cancer Res 2011, 17(24):7673-83.

2. Umbehr MH, Muntener M, Hany T, Sulser T, Bachmann LM: The role of 11C-choline and 18F-fluorocholine positron emission tomography (PET) and PET/CT in prostate cancer: a systematic review and meta-analysis. Eur Urol 2013, 64(1):106-17.

3. Evangelista L, Guttilla A, Zattoni F, Muzzio PC, Zattoni F: Utility of choline positron emission tomography/computed tomography for lymph node involvement identification in intermediate- to high-risk prostate cancer: a systematic literature review and meta-analysis. Eur Urol 2013, 63(6):1040-8.

4. Marzola MC, Chondrogiannis S, Ferretti A, Grassetto G, Rampin L, Massaro A, et al: Role of $18 \mathrm{~F}$-choline PET/CT in biochemically relapsed prostate cancer after radical prostatectomy: correlation with trigger PSA, PSA velocity, PSA doubling time, and metastatic distribution. Clin Nucl Med 2013, 38(1):e26-32.

5. Afshar-Oromieh A, Zechmann CM, Malcher A, Eder M, Eisenhut M, Linhart $H G$, et al: Comparison of PET imaging with a (68)Ga-labelled PSMA ligand and (18)F-choline-based PET/CT for the diagnosis of recurrent prostate cancer. Eur J NuCl Med Mol Imaging 2014, 41(1):11-20.

6. Morigi JJ, Stricker P, Van LP, Tang R, Ho B, Nguyen Q, et al: Prospective Comparison of the detection rate of18F-Fluoromethylcholine and 68GaPSMA-HBED PET/CT in men with prostate cancer with rising PSA post curative treatment, being considered for targeted therapy.LID jnumed.115.160382 [pii]. J Nucl Med 2015, pii : jnumed 115160382 2015, ii.

7. Eiber M, Maurer T, Souvatzoglou M, Beer AJ, Ruffani A, Haller B, et al: Evaluation of Hybrid (6)(8)Ga-PSMA Ligand PET/CT in 248 Patients with Biochemical Recurrence After Radical Prostatectomy. J Nucl Med 2015, 56(5):668-74.

F-18 sodium fluoride ( $\mathrm{NaF}$ ) is highly sensitive compared to bone scintigraphy with Tc99m labelled phos-

Other PET tracers being explored include C-11 acetate targeting lipogenesis, tracers radiolabelling bombesin and targeting gastrin-releasing peptide receptor (GRPR), amino acid transport with anti-1-amino-3-F18-fluorocyclobutane1-carboxylic acid (FACBC) and F-18-fluoro-5 $\alpha$-dihydrotestosterone (FDHT) targeting the androgen receptor 9,10].

This talk reviews the diagnostic utility of PET in prostate cancer.

Published: 2 October 2015 
8. Poulsen MH, Petersen $\mathrm{H}$, Hoilund-Carlsen PF, Jakobsen JS, Gerke $\mathrm{O}$, Karstoft J, et al: Spine metastases in prostate cancer: comparison of technetium-99m-MDP whole-body bone scintigraphy, [(18) F]choline positron emission tomography(PET)/computed tomography (CT) and [(18) F]NaF PET/CT. BJU Int 2014, 114(6):818-23.

9. Jadvar H: Molecular imaging of prostate cancer with PET. J NuCl Med 2013, 54(10):1685-8.

10. Yu CY, Desai B, Ji L, Groshen S, Jadvar H: Comparative performance of PET tracers in biochemical recurrence of prostate cancer: a critical analysis of literature. Am J Nucl Med Mol Imaging 2014, 4(6):580-601.

doi:10.1186/1470-7330-15-S1-015

Cite this article as: Barwick: PET/CT imaging in prostate cancer. Cancer Imaging 2015 15(Suppl 1):O15.

Submit your next manuscript to BioMed Central and take full advantage of:

- Convenient online submission

- Thorough peer review

- No space constraints or color figure charges

- Immediate publication on acceptance

- Inclusion in PubMed, CAS, Scopus and Google Scholar

- Research which is freely available for redistribution

Submit your manuscript at www.biomedcentral.com/submit
Ciomed Central 